\title{
GENETIC INHERITANCE OF GRAIN YIELD AND ITS RELATED TRAITS IN MAIZE (ZEA MAYS L.) UNDER WATER DEFICIT
}

\author{
RAMZAN, M. ${ }^{1 *}-$ AHSAN, ${ }^{1}{ }^{1}-$ SADAQAT, H. A. ${ }^{1}-$ AWAN, F. S. ${ }^{2}$ \\ ${ }^{I}$ Department of Plant Breeding and Genetics, University of Agriculture, Faisalabad, Pakistan \\ ${ }^{2}$ Centre of Agricultural Biochemistry and Biotechnology, University of Agriculture, Faisalabad, \\ Pakistan \\ *Corresponding author \\ e-mail: madiharamzan2301@gmail.com
}

(Received 24 $4^{\text {th }}$ May 2019; accepted $11^{\text {th }}$ Oct 2019)

\begin{abstract}
Drought stress is one of the major yield limiting factors and causes significant yield losses in different crops. This study was conducted to screen the 50 maize accessions of diverse origin of Pakistan against moisture deficit on the basis of their performance vis., plant height, cob length, kernel rows per ear, kernels per ear, leaf area, days to 50\% anthesis, grain yield, 100 -seed weight, chlorophyll contents, stomata size, harvest index and drought index. Drought stress was imposed through alternate irrigation (10 recommended irrigations) and normal irrigation (no drought stress) (15 recommended irrigations). The germplasm consisting of 8 parents and 15 crosses was evaluated in field under normal and water deficit conditions in spring season. Out of these 50 accessions five drought and three drought sensitive lines were selected. The selected drought resistant lines were crossed with drought sensitive lines (testers) in line $\times$ tester mating design and were evaluated on the basis of yield and yield contributing traits. The inbred lines W64TMS and W82-3 expressed higher general combining ability (GCA) for grain yield, and other yield related traits (cobs per plant, grains per cob, 100-seed weight) under normal and water deficit conditions. The F1 hybrids W64TMS $\times$ USSR150 and W82-3 $\times 150 \mathrm{P}-1$ showed higher specific combining ability (SCA) for grain yield and other related traits under normal and drought stress. Positive correlation was observed between grain yield and cob length, cob diameter, kernel rows per ear, kernels per ear, plant height, number of leaves per plant, leaf area, chlorophyll content, 100-seed weight, stomata size and stomata frequency. It was suggested that the present breeding material may be used for the improvement of grain yield and water deficit tolerance in maize.
\end{abstract}

Keywords: moisture deficit, germplasm, accessions, general combining ability

\section{Introduction}

Maize (Zea mays L.) is an important food and feed crop due to its high demand as compared to wheat and rice. In 2020 in developing countries maize demand would increase as compared to wheat and rice owing to high consumption as fresh and treated forms like sweeteners, maize bread, corn flakes, maize chips, corn flour, and corn porridge. Moreover maize is used as raw material in industries like textile, refineries, foundry, fermentation, and food industries for production of ethanol as biofuel for vehicles, corn oil, dextrose, corn syrup and alcohol for beverages. In developed countries 40-80\% maize used as fodder for livestock (Farnham et al., 2003).

Water deficit is a major factor of abiotic stress which diminishes the grain yield of many crops (Aslam et al., 2015). Maize plants are sensitive to water shortage due to extraordinary evaporation and weak root structure (Abayomi et al., 2012). Globally 20$25 \%$ of total planting area of maize is affected by drought stress (Golbashy et al., 2007). Water shortage at flowering stage in maize causes $40-85 \%$ yield loss (Bänziger et al., 2002) and at anthesis to grain filling 40-80\% yield losses are caused. The deficiency of water reduces photosynthesis, turgor in phloem cells and flow of sucrose from 
conducting cells to sink (seeds) (Sevanto et al., 2014). Moisture deficit limits vegetative growth by decreasing the leaf water contents (Valentovic et al., 2006) and stomatal transpiration/conductance (Anjum et al., 2011). Drought stress damages the membranes (Awasthi et al., 2014), chlorophyll (Rahbarian et al., 2011), photosynthesis (Anjum et al., 2011) due to stomatal or non-stomatal link (Sehgal et al., 2018). Drought stress cause severe losses at reproductive growth stage compared to vegetative growth stage owing to flower abortion, poor kernel set and reduced numbers of seeds (Pushpavalli et al., 2014; Seghatoleslami et al., 2008). Moreover, moisture deficit at grain filling stage reduced the seed size owing to slow down of grain filling rate and duration (Moradi et al., 2013; Sehgal et al.,. 2018).

Drought stress is single most important factor which adversely affects the maize production (Nelson et al., 2007; Nuccio et al., 2015). Water deficiency reduced the survival rate of seedling and cause increase of post-pollination embryo abortion ultimately leading to reduction of yield (Chohan et al., 2012; Kakumanu et al., 2012; Mao et al., 2015). Limited supply of water negatively affects plant development and photosynthesis (Yordanov et al., 200). Water deficit results stunted plant growth, tassel blast, top firing, wilting, low plant density, silk delay and poor seed set which ultimately decreases of grain yield (Chen et al., 2015). To improve tolerance against water deficit, the use of genetics is a main factor. Agronomic interventions also have their significance however; genetic solutions are more cost effective and sustainable (Edmeades et al., 2004) as agronomic practices depend on input availability, skill in soil preparation and crop management but genetics can crammed in kernel and easily amended (Campos et al., 2004). Under drought stress, development of drought-resistant germplasm is an effective and feasible approach (Athar and Ashraf, 2009). For breeding it is indispensable to find the superior genotypes to develop the high yielding hybrids (Ganagappa et al., 1997). The general combining ability (GCA) and specific combining ability (SCA) are essential breeding approaches. General combining ability has main character in yield parameters (Ali et al., 2013; Kanwal et al., 2019; Sindagi et al., 1997) and specific combining ability is more effective as compare the general combining ability for kernel yield. The current study was conducted to i) screen inbred lines for various physio-genetic traits under limited water conditions, ii) development of water deficit tolerant F1 crosses in maize and iii) to estimate gene action, general and specific combining ability effects.

\section{Material and methods}

\section{Experimental site, collection and screening of genetic material}

This study was conducted in the field of the Department of Plant Breeding \& Genetics, University of Agriculture, Faisalabad (latitude $31^{\circ} \mathrm{N}$, longitude $73^{\circ} \mathrm{E}$, altitude $184.4 \mathrm{~m}$ above sea level), Pakistan during 2014 to 2016.

The seed of 50 maize genotypes were taken from maize research group of the Department of Plant Breeding \& Genetics, University of Agriculture Faisalabad. The germplasm particularly accomplished for water deficit tolerance and the studied parameters have direct and indirect correlation with water deficit tolerance. Seeds of collected genotypes were multiplied by self-pollination during 2014. Genetic purity within each genotype was maintained by controlled pollination. The collected maize germplasm was evaluated against water deficit stress during spring season under normal and stress condition. Seeds of 50 genotypes were sown in triplicate in the field of the Department of Plant Breeding and Genetics, University of Agriculture Faisalabad. Line 
to line and plant to plant space were kept $0.75 \mathrm{~m}$ and $0.25 \mathrm{~m}$, respectively with total crop area of $40 \times 50 \mathrm{~m}$. Suggested agronomic and plant safety measures were practiced to nourish crop. Two irrigation treatments were:

$\mathrm{T}_{0}$ : Normal irrigations (15 recommended irrigation)

$\mathrm{T}_{1}$ : Alternate irrigation was skipped (10 irrigations)

Drought stress was imposed by skipping the alternate irrigation (10 irrigations) compared to normal (15 recommended irrigations). Data were recorded on ten random plants per replication from each experiment for the physiological and agronomic parameters. The 5 water deficit tolerant lines were selected.

\section{Recording of data}

\section{Number of days to 50\% tasselling, 50\% silking, anthesis-silking interval and leaf area}

Plants with in replication were measured to have started anthesis, if one anther becomes visible. Number of days taken to tasselling was counted from the date of sowing to the time when $50 \%$ plants completed tasselling. Plants with in replication were measured to be at silking if at least one silk on a plant emerges. Number of days to $50 \%$ silking was recorded by counting the number of days from date of sowing to the date when $50 \%$ plants complete emergence of silks. Anthesis-silking interval (ASI) is the period between the maturity tasseling and silking. It was calculated by subtraction of days to $50 \%$ silking from days to $50 \%$ tasseling. For leaf area measurement length and width of three leaves was measured from top, mid and bottom on each selected and guarded plant with measuring tape in $\mathrm{cm}$. Leaf area was calculated with the following equation after taking average (Montgomery and Cheo, 1971):

$$
\text { Leaf area }\left(\mathrm{cm}^{2}\right)=\text { length }(\mathrm{cm}) \times \text { width }(\mathrm{cm}) \times 0.75
$$

\section{Yield and yield contributing traits}

Plant height and numbers of leaves was measured from ten plants per replication with the help of meter rod from tassel to ground surface in centimeters and was averaged. Length of ear was measured after harvesting in $(\mathrm{cm})$ with the help of measuring tape from selected plants of replication. Cob diameter of each plant was calculated with measuring tape in centimeters from 10 selected plants of each entry. Leaf angle was measured from fifth leaf of each plant with the help of protractor from 10 plants of each entry. Leaf rolling was measured of each plant by scaling from 1 to 5 from 10 selected plants of each entry.

Numbers of grain rows per ear were counted from each cob of the selected 10 plants and was averaged. The total number of kernels threshed from the ears was counted manually. It was recorded in grams with an electronic balance from three samples obtained each from the bulk grain produce obtained from the ear-marked plants and was averaged. The kernels of each ear were threshed separately and weighed with electric balance. Harvest index was calculated from each plant per replication with the help of following formula. The biological yield was recorded by drying complete plants under shade which was used for the calculations of total harvesting index.

$$
\mathrm{HI}=(\text { Grain yield } / \text { Biological yield }) \times 100
$$

Drought index was calculated for selected plants with the help of following formula: 
$\mathrm{DI}=\frac{\text { Yield under drought condition }}{\text { Yield under normal condition }}+\frac{\text { Mean performance under drought condition }}{\text { Mean performance under normal condition }}$

\section{Biometrical approaches}

Analysis of variance

The recorded data on maize germplasm for assessment of variability were analyzed using analysis of variance following Steel et al. (1997). A computer software Statistical was used for the analysis.

Line $\times$ Tester analysis was conducted as proposed by Kempthorne (1957) to estimate the GCA and SCA effects. Heterosis over mid parent and better parent was determined following the method of Falconer and Mackay (1996). To find the strength of relationship among traits correlation analysis was used as proposed by Kwon and Torrie (1964).

Combining ability effects were calculated according to following formulae:

Estimation of general combining ability (GCA) effects

$$
\begin{aligned}
& \text { Lines: } \mathrm{gi}=\{(\mathrm{xj} . . / \mathrm{tr})-(\mathrm{x} . . . / \mathrm{ltr})\} \\
& \text { Testers: } \mathrm{gt}=\{(\mathrm{x} . \mathrm{j} . / \mathrm{lr})-(\mathrm{x} . . / / \mathrm{ltr})\}
\end{aligned}
$$

where: $1=$ number of lines; $\mathrm{t}=$ number of testers; $\mathrm{r}=$ number of replications; $\mathrm{xi} . .=$ Total number of $\mathrm{F}_{1}$ resulting from crossing ith lines with all the testers; $\mathrm{x} . . .=$ Total of all the crosses.

Estimation of specific combining ability (SCA) effects

$$
s i=\{(x i j .) / r)-(x i . . / \text { tr })-(x . j . / \text { lr })+x \ldots / \text { ltr }
$$

where: $x i j=$ total of $F_{1}$ resulting from crossing ith lines with $j$ th tester; $x i=$ total of all the crosses of ith line with all testers; $x j=$ Total of all the crosses of $j$ th tester with all lines.

\section{Data analysis}

The means were computed and data for all the traits of genotypes were subjected to ordinary analysis of variance (Steel et al., 1997) in order to determine genotypic differences. Biplot analysis based on Principal Component Analysis (PCA) was made using statistical package (XLSTAT) for the selection of tolerant and susceptible genotypes on the basis of all traits along with yield.

\section{Results}

\section{Genetic variability}

Significant differences were observed among the genotypes for all studied traits. Treatments were significantly different for all the traits except leaf rolling. Genotypes $\times$ treatments interaction was also significant for all the traits (Table Al in the Appendix).

\section{Principle component analysis}

Genotype away from origin is good performer relative to the genotypes nearer to the origin. Principal component analysis (PCA 3) showed that accessions 4, 19, 12, 37, 26 
and 28 were fall in quadrate I and accessions $30,33,50,39,22$ and 13 were fall in quadrate IV. The PCA 4 showed that accessions 4, 19, 26, 37 and 9 were fall in quadrate I and accessions 1, 30 and 50 were fall in quadrate IV. The genotypes in quadrate I was selected as lines and in quadrate IV was selected as testers (Figs. 1 and 2).

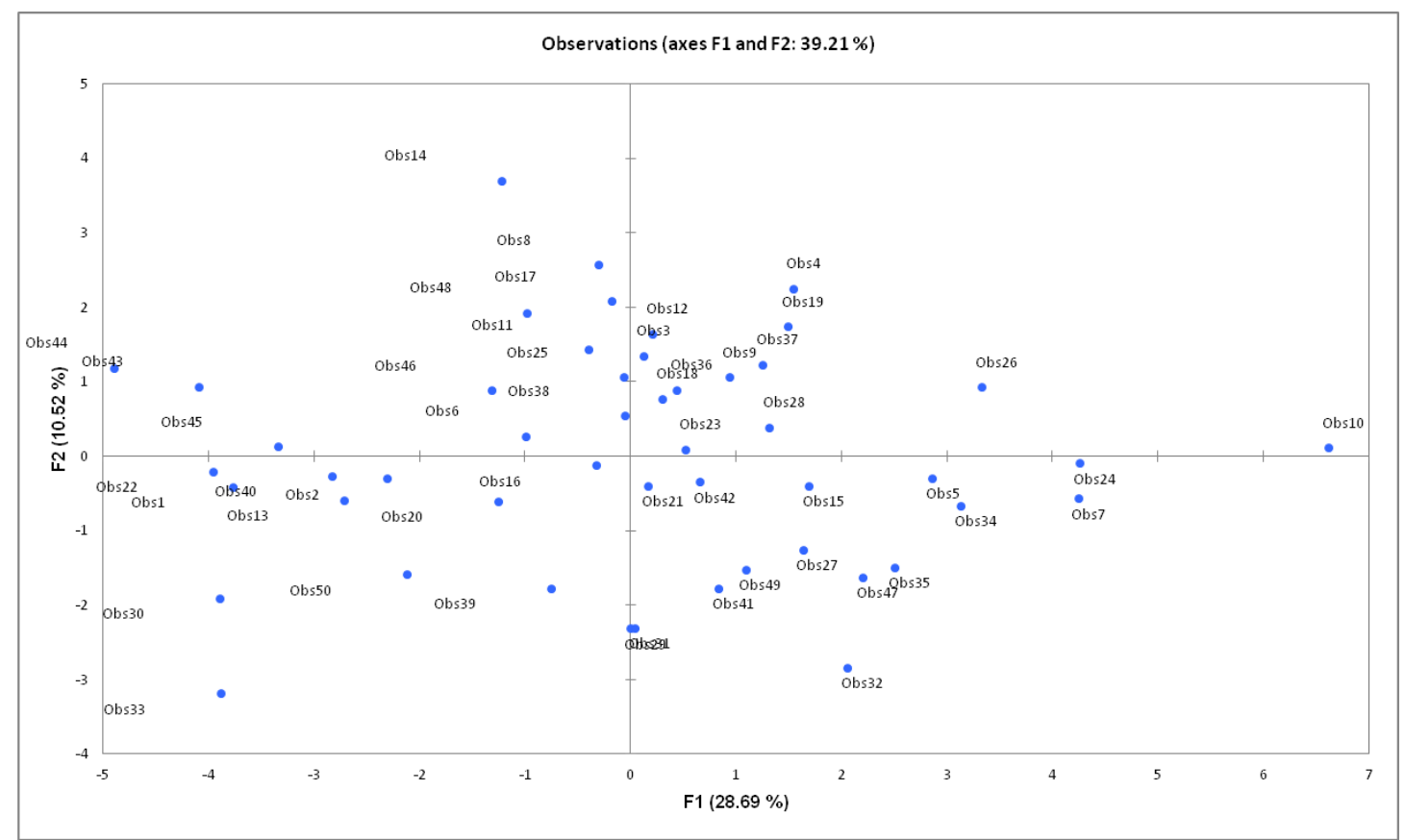

Figure 1. Biplot analysis based on principal components analysis (PCA) for maize genotypes under normal conditions

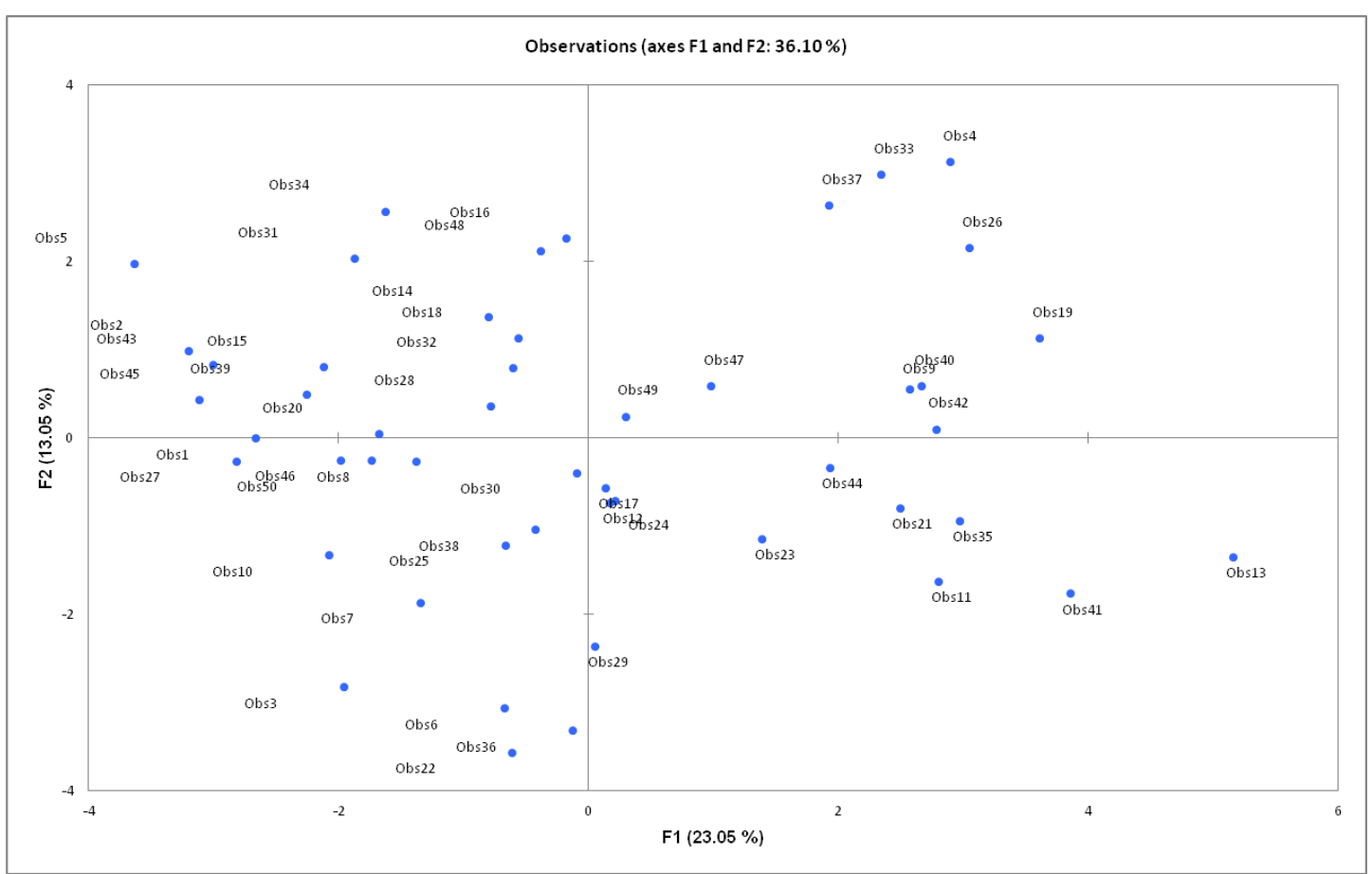

Figure 2. Biplot analysis based on principal components analysis (PCA) for maize genotypes under water deficit conditions 


\section{General combining ability effects}

Under normal condition (no drought stress) the general combining ability (GCA) test indicated that lines A427-2 showed maximum GCA effects for leaf area and leaf temperature. Line W64TMS revealed maximum values of GCA for seed per cob, rows of kernel per cob, 100 seed weight, and harvest index. For grain yield, chlorophyll content, stomata size and harvest index significant effects were observed in line W82-3 (Table 1). Maximum GCA was observed in line A556 for days to 50\% anthesis, leaf area, leaf angle and leaf temperature. Line W64TMS expressed positive significant GCA effects for grain yield.

Table 1. General combining ability effects of lines and testers for various traits of maize under normal conditions

\begin{tabular}{|c|c|c|c|c|c|c|c|c|}
\hline \multirow{2}{*}{ Traits } & \multicolumn{5}{|c|}{ Lines } & \multicolumn{3}{|c|}{ Testers } \\
\hline & A427-2 & W64TMS & W82-3 & $\mathrm{N}-18$ & A556 & M14 & USSR150 & 150P-1 \\
\hline Plant height & 7.911 & $-8.422 *$ & -0.311 & -5.311 & 6.133 & $9.711 *$ & -0.755 & $-8.955^{*}$ \\
\hline Days to $50 \%$ silking & 0.00 & -0.22 & -1.111 & -0.22 & -1.55 & -0.244 & -0.44 & $0.688^{*}$ \\
\hline Days to $50 \%$ anthesis & -0.155 & -0.266 & $-1.37^{*}$ & 0.288 & $1.511^{* *}$ & 0.111 & -0.355 & 0.244 \\
\hline Interval & -0.177 & -0.178 & -0.511 & $0.489 *$ & 0.377 & $0.333^{*}$ & 0.066 & $-0.400 *$ \\
\hline Number of leaves & 0.311 & 0.644 & $-0.688^{*}$ & -0.577 & 0.311 & -0.466 & 0.200 & 0.266 \\
\hline Leaf area & $25.911^{*}$ & $-29.97 *$ & $-38.53 *$ & -19.97 & $62.57 * *$ & 10.044 & $24.177^{*}$ & $-34.22 *$ \\
\hline Leaf angle & -0.866 & -1.422 & 0.577 & -1.088 & $2.800^{*}$ & 0.911 & 0.311 & $-1.22 *$ \\
\hline Leaf rolling & $-0.09 *$ & 0.004 & $0.111^{*}$ & -0.043 & 0.02 & $-0.115^{*}$ & $0.04 *$ & $0.074 *$ \\
\hline Grain per $\mathrm{Cob}$ & 0.488 & $38.266 * *$ & $-11.06^{*}$ & $-21.844 * *$ & -5.84 & $-17.17 * *$ & $-21.77 * *$ & $38.95^{* *}$ \\
\hline kernel rows per ear & 0.003 & $0.466^{*}$ & -0.111 & 0.333 & $-0.66^{*}$ & 0.133 & 0.00 & -0.133 \\
\hline Cob diameter & $-0.844 *$ & 0.488 & $-0.622 *$ & $0.822 *$ & 0.155 & 0.022 & 0.088 & -0.11 \\
\hline Cob length & 0.311 & 0.311 & -0.022 & -0.244 & -0.355 & $0.733^{*}$ & $-0.66^{*}$ & -0.066 \\
\hline Plant yield & 4.334 & $9.788^{*}$ & $8.897 *$ & $-5.825^{*}$ & $-17.19^{* *}$ & 0.248 & -0.161 & -0.086 \\
\hline $100-S W$ & -0.41 & $1.24 *$ & 0.379 & 0.052 & -1.23 & 0.652 & -0.794 & 0.142 \\
\hline Chlorophyll content & $-5.321 *$ & -0.421 & $3.411 *$ & 2.067 & 0.264 & -2.128 & 0.284 & 1.843 \\
\hline Leaf temperature & $0.897 *$ & 0.641 & $-2.15^{*}$ & -0.38 & $1.008^{*}$ & -0.593 & $1.04 *$ & -0.453 \\
\hline Stomata size & $-33.70 *$ & -1.179 & $14.36^{*}$ & $20.19 * *$ & 0.32 & $13.70^{*}$ & -7.22 & -6.47 \\
\hline Stomata frequency & 0.111 & 0.555 & $-0.787 *$ & $0.889^{*}$ & $-0.777^{*}$ & 0.22 & 0.15 & -0.37 \\
\hline Epidermal cells & $-0.466^{*}$ & $0.533^{*}$ & -0.24 & 0.200 & -0.022 & $-0.66^{*}$ & 0.002 & $0.66^{*}$ \\
\hline Harvest index & -0.45 & $1.162 *$ & $0.979 *$ & -0.487 & $-1.204 *$ & $-1.152 * *$ & -0.259 & $1.412^{* * *}$ \\
\hline Drought index & $-0.034 *$ & $0.020^{*}$ & 0.008 & 0.003 & 0.002 & -0.005 & 0.006 & -0.004 \\
\hline
\end{tabular}

*Significant at 0.05 probability level. **Significant at 0.01 probability level

Under normal condition (no drought stress) testers M14 expressed good GCA effects for plant height, anthesis-silking interval, and stomata size. Positive GCA effects were observed in USSR150 for leaf area, leaf rolling and leaf temperature. Tester 150p-1 considered s good general combiner leaf rolling, grains per cob, epidermal cells and harvest index. The tester M14 had positive significant GCA effect for cob length, it is good general combiner because cob length is directly proportional to kernels per ear.

Under water deficit conditions genotypes showed different response for GCA in all parameters (Table 2). Line A427-2 considered as good combiner for plant height, days taken to $50 \%$ anthesis, anthesis-silking interval, chlorophyll content, stomata size and stomata frequency due to good GCA. Line W64TMS had greater effects for anthesissilking interval, grain per cob, grain yield, and harvest index. The W82-3 line revealed good GCA effects for days to $50 \%$ silking, days to $50 \%$ anthesis, leaves per plant, cob 
length grain yield, leaf temperature and harvest index. The line A556 exhibited significant GCA effects for cob diameter and cob length. In testers M14 showed favorable GCA effects for leaves per plant, cob diameter, chlorophyll content and leaf temperature. Tester USSR150 had good GCA effects for days taken to 50\% silking, days taken to $50 \%$ anthesis, grain yield,100 seed weight and stomata frequency (Table 2).

Table 2. General combining ability effects of lines and testers for various traits of maize under water deficit conditions

\begin{tabular}{|c|c|c|c|c|c|c|c|c|}
\hline \multirow{2}{*}{ Traits } & \multicolumn{5}{|c|}{ Lines } & \multicolumn{3}{|c|}{ Testers } \\
\hline & A427-2 & W64TMS & W82-3 & $\mathrm{N}-18$ & A556 & M14 & USSR150 & 150P-1 \\
\hline Plant height & $7.78^{*}$ & 2.77 & -0.66 & 3.00 & $-12.88 * *$ & 1.48 & -2.77 & 1.288 \\
\hline Days to $50 \%$ silking & 0.155 & $-1.73 * *$ & $1.488^{* *}$ & $-0.844^{*}$ & $0.933^{*}$ & $-1.977 * *$ & $1.488 * *$ & $0.488^{*}$ \\
\hline Days to $50 \%$ anthesis & $0.600^{*}$ & $-1.400^{* *}$ & $1.266^{* *}$ & $-1.288^{* *}$ & $0.822 *$ & $-2.466^{* *}$ & $1.600^{* *}$ & $0.866^{*}$ \\
\hline Interval & $0.444^{*}$ & $0.333^{*}$ & -0.222 & $-0.444^{*}$ & -0.111 & $-0.488^{*}$ & 0.111 & $0.377 *$ \\
\hline Number of leaves & 1.33 & -0.22 & $0.555^{*}$ & $-0.676^{*}$ & -1.00 & $0.511^{*}$ & $-0.622 *$ & 0.111 \\
\hline Leaf area & -1.866 & 5.244 & -3.53 & 2.355 & -2.200 & 9.800 & -2.466 & -7.33 \\
\hline Leaf angle & 1.22 & 1.22 & $-5.44 *$ & $2.89^{*}$ & 0.11 & 1.55 & $-2.77 *$ & 1.22 \\
\hline Leaf rolling & -0.02 & -0.05 & -0.04 & 0.02 & $0.097^{*}$ & $-0.284^{*}$ & $0.125^{*}$ & $0.159 *$ \\
\hline Grain per Cob & -0.86 & $27.46^{*}$ & 5.133 & -18.311 & -13.42 & -23.00 & -23.8 & $46.8^{*}$ \\
\hline kernel rows per ear & -0.178 & 0.044 & -0.400 & 0.266 & 0.27 & 0.266 & $-0.66^{*}$ & $0.400 *$ \\
\hline Cob diameter & $-0.511 *$ & -0.066 & -0.067 & -0.288 & $0.933^{*}$ & $0.755^{*}$ & -0.177 & $-0.577 *$ \\
\hline Cob length & $-0.955^{*}$ & 0.044 & $0.600^{*}$ & -0.177 & $0.488^{*}$ & 0.089 & -0.244 & 0.155 \\
\hline Plant yield & 1.606 & $6.504 * *$ & $6.751^{* *}$ & $-8.129 * *$ & $-6.733 * *$ & -1.982 & $4.366^{*}$ & $-2.383 *$ \\
\hline $100-\mathrm{SW}$ & -0.861 & 0.517 & 0.169 & -0.215 & 0.389 & 0.237 & $0.835^{*}$ & -1.07 \\
\hline Chlorophyll content & $3.073 * *$ & 1.362 & 1.151 & $-2.404^{*}$ & $-3.182 *$ & $2.437 *$ & $1.677 *$ & $-4.115^{*}$ \\
\hline Leaf temperature & 0.144 & -0.522 & $1.033^{*}$ & $-1.388^{*}$ & $0.733^{*}$ & $1.431 *$ & $-0.58^{*}$ & $-0.842 *$ \\
\hline Stomata size & $18.65^{* *}$ & $-12.92 *$ & $-12.96^{*}$ & -0.97 & 8.21 & 4.48 & -4.34 & -0.140 \\
\hline Stomata frequency & $0.489^{*}$ & -0.066 & -0.400 & -0.288 & 0.266 & $-0.377 *$ & $0.422 *$ & -0.044 \\
\hline Epidermal cells & -0.044 & $0.511 *$ & -0.155 & -0.266 & -0.044 & -0.266 & -0.066 & 0.33 \\
\hline Harvest index & $-0.782 *$ & $1.004 *$ & $1.208^{*}$ & -0.525 & $-0.904 *$ & $-1.086^{* *}$ & -0.494 & $1.580^{* *}$ \\
\hline
\end{tabular}

$*$ Significant at 0.05 probability level. **Significant at 0.01 probability level

\section{Specific combining ability effects}

Under normal conditions (no drought stress) specific combining ability (SCA) effects of crosses indicated that cross A427 $\times$ M14 showed positive SCA effects for kernel rows per ear and leaf temperature. Cross W64TMS $\times$ USSR150 had positive and significant SCA effects for cob length, anthesis-silking interval, plant yield, and harvest index (Table 3). Cross W64TMS $\times 150 \mathrm{P}-1$ showed positive and significant SCA effects for cob diameter, kernel rows per ear, grins per cob, plant yield, chlorophyll content, stomata size, and harvest index. Cross W82-3 $\times 150 \mathrm{P}-1$ exhibited positive and significant SCA effects for cob length, grains per cob, plant yield, and harvest index. Cross N-18 $\times$ M14 showed positive and significant SCA effects for cob length, cob diameter, kernel rows per cob, anthesis-silking interval, plant yield and stomata size (Table 3). Under drought stress significant SCA effects were observed in cross A427 $\times$ M14 for days to $50 \%$ silking, days to $50 \%$ anthesis and anthesis-silking interval, and stomata size. Cross A427 × 150P-1 exhibited significant SCA effects for number of leaves per plant, kernel rows per cob, leaf angle, anthesis-silking interval, stomata size, and harvest index. Cross W64TMS $\times$ USSR150 revealed positive and significant SCA effects for plant height, leaf area, anthesis-silking interval, plant yield, stomata 
frequency, and harvest index (Table 4). Cross W82-3 $\times 150 \mathrm{P}-1$ showed positive and significant SCA effects for number of leaves per plant, cob length, number of grains per cob, plant yield, and harvest index. Cross N-18 $\times$ M14 had positive SCA effects for plant height, number of leaves per plant, leaf area, kernel rows per cob, leaf angle and leaf temperature. Cross N-18 $\times$ USSR150 revealed positive and significant SCA effects for cob diameter, anthesis-silking interval and 100 seed weight. Cross N-18 $\times 150 \mathrm{P}-1$ showed positive and significant SCA values for cob diameter, anthesis-silking interval and 100 seed weight (Table 4).

\section{Discussion}

Drought stress negatively affected the grain yield and yield contributing traits in maize (Tables 2 and 3). Different management approaches are used to avoid yield losses in maize such as water management and agronomic practices as sowing on beds etc. However, developments of drought tolerant germplasm are the main tools which are explored across the world to improve the production of maize under moisture deficit conditions (Ali et al., 2017; Aslam et al., 2015). The different genotypes of maize had genetic variability against drought stress (Tables $1-3$ ) which could be explored by the screening of different germplasms (Aslam et al., 2015). To develop tolerant genotypes creation of genetic variability and gene combination through intercrossing of targeted parents is the main practices most widely used owing to intercrossing followed by suitable selection which develop an ideotype plant which is suitable for environment specific cultivation (Bänziger et al., 2000; Kanwal et al., 2019; Mahmood et al., 2019). Maximum GCA was recorded in line A556 for days to 50\% anthesis, leaf area and line W64TMS had significant GCA for grain yield (Tables 1-3) as assessment of yield limiting traits with morphological approaches help conventional breeding for yield improvements (Cattivelli et al., 2008; Ali et al., 2013). The selection of superior traits is a good general combiner for evolving high yield hybrids through transgressive segregation, the similar findings were reported by (Ivy and Howlader, 2000; Paul and Duara, 1991).

The cross W82-3 × 150P-1 had positive SCA effects for number of leaves per plant, cob length, number of grains per cob, plant yield, and harvest index (Tables 1-4). Cross W64TMS $\times$ USSR150 had significant SCA effects for cob length, anthesis-silking interval, plant yield, and harvest index (Table 3), the longer is ear length the higher will be grain yield and similar findings were found by different scientist across the world (Konak et al., 2001; Mendoza et al., 2001; Rahman et al., 2010). Against drought stress, yield and yield contributing traits are primary target for yield improvement. Moreover, secondary traits are also important for yield improvements as they had strong positive correlation with grain yield and are easy to measure (Edmeades et al., 2001). The association of near isogenic lines helped the breeder to find association of targeted secondary traits with economic yield (Bänziger et al., 2000; Ali et al., 2014) as economic yield is the ultimate goal. Under drought stress, testers M14 had positive GCA effects for leaves per plant, cob diameter, chlorophyll content and leaf temperature. While, tester USSR150 had good GCA for days taken to 50\% silking, days taken to 50\% anthesis, grain yield, 100 seed weight and stomata frequency (Table 2) and the intrapopulation improvement for drought stress can be done through plant selection, pre-performance, test crosses using individual plants and parental testers (Bänziger et al., 2000; Ali et al., 2016). 
Table 3. Specific combining ability affects under normal conditions

\begin{tabular}{|c|c|c|c|c|c|c|c|c|c|c|c|c|c|c|c|c|c|c|c|c|}
\hline Crosses & PH & NOL & LA & CL & CD & KR & K/E & $L$ ang & DS & DA & Int & PY & $100 \mathrm{SW}$ & LR & LT & Chl. & SS & SF & EC & HI \\
\hline $\begin{array}{c}\mathrm{A} 427 \times \\
\mathrm{M} 14\end{array}$ & 5.95 & 0.35 & -6.71 & 0.155 & $-1.35 *$ & $1.20 *$ & 14.178 & 0.53 & $-1.20^{*}$ & -0.77 & 0.44 & -4.05 & 1.42 & \begin{tabular}{|l|}
$-0.10 *$ \\
\end{tabular} & $1.78^{*}$ & 4.16 & $-27.6^{*}$ & 0.55 & 0.66 & $-1.322 *$ \\
\hline $\begin{array}{c}\text { A427 } \times \\
\text { USSR150 }\end{array}$ & 6.28 & 0.35 & 38.84 & $-1.84 * *$ & -0.68 & -0.57 & 4.067 & 2.75 & $.35 * *$ & $1.66^{*}$ & -0.55 & 8.97 & $-4.88 *$ & $0.16^{* *}$ & $1.40^{*}$ & -3.63 & $-39.5 * *$ & -0.55 & -0.66 & 0.223 \\
\hline $\begin{array}{l}\text { A427 } \times \\
150 \mathrm{P}-1\end{array}$ & $-16.82^{*}$ & $1.35^{*}$ & $58.06 *$ & -0.17 & 0.42 & $-1.35^{*}$ & 7.067 & $-6.91 *$ & 0.91 & 0.11 & -0.55 & $-15.6^{*}$ & -0.92 & -0.02 & $1.90^{*}$ & $-7.77 *$ & $-54.4 * *$ & -0.22 & $0.77^{*}$ & $1.513^{*}$ \\
\hline $\begin{array}{c}\text { W64TMS } \times \\
\text { M14 }\end{array}$ & $14.84 *$ & $1.57^{*}$ & -17.1 & -0.62 & -0.02 & $-1.13^{*}$ & $38.178 * *$ & 0.75 & 0.35 & $-1.55^{*}$ & $-1.88 * *$ & 3.79 & 1.400 & $0.155^{*}$ & $2.06^{*}$ & -3.46 & -14.2 & 0.44 & $1.00 *$ & -0.546 \\
\hline $\begin{array}{c}\text { W64TMS } \times \\
\text { USSR150 }\end{array}$ & $-48.6^{* * *}$ & 1.02 & $-111^{* * *}$ & $0.82 *$ & -0.02 & 0.53 & 3.178 & $.46 * *$ & $-1.42^{*}$ & -0.44 & $0.88^{*}$ & $32.00 * *$ & 1.50 & 0.028 & 1.27 & $-7.62 *$ & $-26.9^{*}$ & $1.44 *$ & 0.55 & $2.784 * *$ \\
\hline $\begin{array}{c}\text { W64TMS } \times \\
150 \mathrm{P}-1\end{array}$ & $-18.91^{*}$ & 0.02 & $-74.51^{*}$ & 0.22 & $1.24 *$ & $2.00 * *$ & $156.77 * *$ & 1.466 & 0.00 & -0.31 & $-0.95 *$ & $11.91 *$ & 1.82 & 0.134* & $-2.79 * *$ & $16.78 * *$ & $30.6^{*}$ & $-1.04 *$ & $1.66^{*}$ & $5.957 * *$ \\
\hline $\begin{array}{c}\text { W82-3 } \times \\
\text { M14 }\end{array}$ & 755 & $-1.64 *$ & 27.04 & 0.55 & $-1.42 *$ & $-1.77 * *$ & $-46.66^{* * *}$ & 688 & $1.22 *$ & 0.46 & -0.62 & 1.43 & -1.91 & 0.054 & $-7.03^{* *}$ & $7.51 *$ & $50.5^{* *}$ & $1.48 *$ & $-1.33^{*}$ & $1.177^{*}$ \\
\hline $\begin{array}{l}\text { W82-3 } \times \\
\text { USSR150 }\end{array}$ & $17.31 *$ & \begin{tabular}{|l|}
-0.97 \\
\end{tabular} & 5.6 & 0.22 & 0.022 & 0.77 & 9.00 & 1.355 & $-1.88^{*}$ & $-1.42^{*}$ & 0.044 & 2.45 & $2.73^{*}$ & -0.04 & 0.96 & -0.81 & -15.5 & -0.48 & 0.11 & -0.649 \\
\hline $\begin{array}{c}\text { W82-3 } \times \\
150 \mathrm{P}-1\end{array}$ & -11.68 & 0.57 & $-132 * *$ & $1.11^{*}$ & $-1.42 *$ & .00 & $4.44 * *$ & -0.311 & 0.22 & -0.75 & $-0.95 *$ & $10.43 *$ & 1.05 & $0.135^{*}$ & $-1.63 *$ & -2.37 & -3.54 & $-1.48 *$ & 0.00 & $1.533^{*}$ \\
\hline $\begin{array}{c}\mathrm{N}-18 \times \\
\text { M14 }\end{array}$ & -8.13 & $-2.31 *$ & $-71.8^{*}$ & $2.22^{*}$ & $1.57 *$ & $2.00 * *$ & 5.778 & -0.866 & $-2.55^{* *}$ & 0.02 & $2.15^{* *}$ & $10.04 *$ & 1.66 & $-0.32 *$ & $-2.86 * *$ & $-7.70 *$ & $59.88^{* * *}$ & 0.84 & $-1.44 * *$ & 0.698 \\
\hline $\begin{array}{c}\mathrm{N}-18 \times \\
\text { USSR150 }\end{array}$ & -5.04 & 0.62 & -13.11 & $-1.711 * *$ & 1.778 & 0.133 & $-99.28 * *$ & 1.00 & -0.80 & -0.91 & -0.15 & -8.15 & -1.99 & 0.027 & 0.31 & $11.82 * *$ & $42.61 * *$ & $2.15^{* * *}$ & $1.33^{*}$ & $-2.76^{* *}$ \\
\hline $\begin{array}{l}\text { N-18 } \times \\
150 P-1\end{array}$ & 10.28 & $-2.04 *$ & 10.77 & -0.71 & -0.55 & -0.64 & $-61.06^{* *}$ & -1.77 & 0.42 & 0.53 & 0.17 & $-15.96^{*}$ & 1.42 & 0.044 & -1.30 & 3.58 & 12.80 & 0.377 & -0.66 & $-1.464 *$ \\
\hline $\begin{array}{c}\text { A556 } \times \\
\text { M14 }\end{array}$ & $17.17 *$ & -0.04 & $84.66^{* *}$ & $1.28^{*}$ & $1.22 *$ & 0.24 & $-58.4 *$ & 1.22 & $1.64 *$ & $2.64 *$ & $1.17^{*}$ & $-10.06^{*}$ & 0.82 & $-0.28 * *$ & $2.63^{*}$ & $-9.31 *$ & -6.48 & 0.377 & $-1.55^{* *}$ & $-4.35^{* *}$ \\
\hline $\begin{array}{c}\text { A556 } \times \\
\text { USSR150 }\end{array}$ & $25.51 *$ & 0.17 & $224.77 * *$ & $-1.48^{*}$ & -0.55 & $-0.86^{*}$ & $-47.62^{*}$ & $6.22 *$ & -0.91 & $-1.02 *$ & 0.17 & $-36.2 * *$ & -2.13 & 0.07 & $2.32 *$ & 1.96 & -3.90 & $-1.62 * *$ & $-1.33^{*}$ & $-1.147 *$ \\
\hline $\begin{array}{l}\text { A556 } \times \\
150 \mathrm{P}-1\end{array}$ & 2.06 & 0.95 & -23.11 & -0.04 & -0.22 & -0.53 & 10.37 & 2.33 & 1.64 & 1.75 & .62 & $9.10^{*}$ & -2.02 & -0.02 & 0.96 & -3.13 & -4.08 & 0.711 & $0.88^{*}$ & $-1.633^{*}$ \\
\hline
\end{tabular}

$\mathrm{PH}=$ plant height $\mathrm{NOL}=$ number of leaves, $\mathrm{LA}=\mathrm{Leaf}$ area $\mathrm{CL}=\mathrm{Cob}$ length $\mathrm{CD}=\mathrm{Cob}$ diameter $\mathrm{KR}=$ Kernel rows per ear, $\mathrm{K} / \mathrm{C}=\mathrm{Kernel}$ per ear $\mathrm{L}$ ang $=\mathrm{Leaf}$ angle, $\mathrm{DS}=\mathrm{days}$ to silking, $\mathrm{DA}=\mathrm{Days}$ anthesis, Int $=$ Interval, $\mathrm{PY}=$ plant yield, $100 \mathrm{SW}=100$ Seed weight, $\mathrm{LR}=$ Leaf rolling, $\mathrm{LT}=$ Leaf temperature, $\mathrm{Chl}=$ Chlorophyll content, $\mathrm{SS}=\mathrm{Stomata}$ size, $\mathrm{SF}=\mathrm{Stomata}$ frequency, $\mathrm{EC}=\mathrm{Epidermal}$ cells, $\mathrm{HI}=$ Harvest index 
Table 4. Specific combining ability affects under water deficit conditions

\begin{tabular}{|c|c|c|c|c|c|c|c|c|c|c|c|c|c|c|c|c|c|c|c|c|}
\hline Crosses & $\mathbf{P H}$ & NOL & LA & CL & CD & KR & $\mathbf{K} / \mathbf{E}$ & $L$ ang & DS & DA & Int & PY & $100 \mathrm{SW}$ & LR & LT & Chl & SS & SF & EC & HI \\
\hline $\begin{array}{c}\text { A427 } \times \\
\text { M14 }\end{array}$ & -6.37 & 0.26 & -3.13 & 0.022 & 0.24 & 0.177 & 13.33 & $-4.88 *$ & $3.97 * *$ & $5.133^{* *}$ & $1.155^{* *}$ & -2.70 & 0.96 & 0.024 & $-1.09^{*}$ & 0.073 & $28.77^{*}$ & -0.28 & $1.37 *$ & -0.938 \\
\hline $\begin{array}{c}\text { A427 } \times \\
\text { USSR150 }\end{array}$ & 9.28 & -0.51 & -15.9 & $-1.31 *$ & $2.20^{* *}$ & $-2.04 * *$ & $23.00^{*}$ & 0.11 & $7.53^{* *}$ & $7.133 * *$ & -0.400 & $12.23^{* *}$ & $-2.00^{*}$ & $0.404 * *$ & -0.76 & -0.64 & 0.026 & $1.26^{*}$ & -0.51 & -0.938 \\
\hline $\begin{array}{l}\text { A427 } x \\
150 P-1\end{array}$ & 6.06 & $1.04 *$ & -15.8 & $-1.53 * *$ & $-1.20 * *$ & $1.066^{*}$ & -1.66 & $6.77 *$ & $-5.02 * *$ & $-3.533 * *$ & $1.488 * *$ & $-13.6^{* *}$ & $-2.07 *$ & $0.482 * *$ & $-2.65 * *$ & $-3.10 *$ & $20.9 *$ & $1.60 * *$ & -0.51 & $1.357 *$ \\
\hline $\begin{array}{c}\text { W64TMS } \\
\times \text { M14 }\end{array}$ & 0.400 & $1.93 * *$ & 6.64 & 0.24 & 0.355 & $-1.60 * *$ & $37.44 * *$ & 0.11 & 0.311 & 0.355 & 0.044 & 1.59 & 0.72 & -0.07 & 0.43 & 2.11 & -18.5 & 0.155 & 0.60 & -0.464 \\
\hline $\begin{array}{c}\text { W64TMS } \\
\times \\
\text { USSR150 }\end{array}$ & $14.95^{*}$ & $-0.73^{*}$ & $37.86 *$ & -0.42 & $-1.53 * *$ & -0.26 & -11.77 & -3.77 & $-5.13 * *$ & -4.422 & 0.711* & $23.46^{* *}$ & 1.68 & $0.173^{*}$ & $-3.35^{* *}$ & $3.52 *$ & $-29.7 *$ & $1.26^{*}$ & $1.04 *$ & $2.500 * *$ \\
\hline $\begin{array}{l}\text { W64TMS } \\
\times 150 \mathrm{P}-1 \\
\end{array}$ & -5.11 & $-1.93 * *$ & $4.2^{*}$ & $1.022 *$ & -0.48 & $1.77 * *$ & $159.13 * *$ & 2.77 & $1.84 * *$ & $3.066^{* *}$ & $1.22 * *$ & $7.30 *$ & -1.48 & 0.094 & -0.41 & $-5.60 * *$ & $-20.9 *$ & $-1.75^{* *}$ & 0.84 & $5.856 * *$ \\
\hline $\begin{array}{c}\text { W82-3 } \times \\
\text { M14 }\end{array}$ & 2.55 & $1.28 * *$ & 18.02 & 0.68 & $1.06^{*}$ & $0.88^{*}$ & $-24.53^{*}$ & -0.55 & $-2.26 * *$ & $-3.60 * *$ & $-1.33 * *$ & -1.95 & -1.52 & $-0.33^{* *}$ & $3.58^{* *}$ & -0.55 & 10.77 & -0.20 & $-1.04 *$ & $2.863 * *$ \\
\hline $\begin{array}{c}\text { W82-3 } \times \\
\text { USSR150 }\end{array}$ & -2.00 & 0.17 & -27.2 & -0.53 & 0.40 & $1.33^{*}$ & 12.13 & $-7.22 *$ & $2.84 * *$ & $3.400 * *$ & $0.55^{*}$ & -2.63 & 0.57 & -0.10 & -0.30 & 0.322 & $-17.17^{*}$ & -0.53 & 0.28 & $-1.134 *$ \\
\hline $\begin{array}{c}\text { W82-3 } \times \\
\text { 150P-1 }\end{array}$ & 0.66 & $2.40 * *$ & 1.911 & $1.91 * *$ & $-0.71 *$ & $-1.33 *$ & $84.91 * *$ & 1.11 & 0.511 & 0.622 & 0.111 & $6.61 *$ & -1.51 & 0.000 & $2.45^{* *}$ & -1.45 & 7.40 & $-0.97 *$ & 0.40 & $1.693 *$ \\
\hline $\begin{array}{c}\mathrm{N}-18 \times \\
\text { M14 }\end{array}$ & $36.22 * *$ & $1.06^{*}$ & $36.13 *$ & -0.42 & -0.26 & $2.00 * *$ & 0.689 & $8.88 * *$ & $-6.93 * *$ & $-8.488 * *$ & $-1.55 * *$ & -4.94 & -1.33 & $-0.51 * *$ & $1.33^{*}$ & 0.322 & -7.09 & $-1.86^{*}$ & $-1.15^{*}$ & -0.414 \\
\hline $\begin{array}{c}\mathrm{N}-18 \times \\
\text { USSR150 } \\
\end{array}$ & $-18.17 *$ & $-1.3 * *$ & -9.66 & 0.622 & $0.57 *$ & $-1.95 * *$ & $-95.4 * *$ & 0.44 & $-1.155^{*}$ & -0.533 & $0.622 *$ & $-6.66^{*}$ & $2.33^{*}$ & 0.124 & $-1.49^{*}$ & 2.52 & -12.2 & -0.28 & 0.11 & $-3.02 * *$ \\
\hline $\begin{array}{l}\text { N-18 } \times \\
150 P-1\end{array}$ & -6.51 & $-1.44 * *$ & -3.44 & -0.377 & -0.20 & 0.48 & $-43.13 * *$ & -2.88 & $3.73 * *$ & $1.800^{* *}$ & $-1.93 * *$ & $-13.74 * *$ & -0.37 & -0.019 & $-2.09 * *$ & $-4.76^{*}$ & 7.08 & 0.266 & -0.77 & -0.121 \\
\hline $\begin{array}{c}\text { A556 } \times \\
\text { M14 }\end{array}$ & $-24.06^{* * *}$ & $-1.88 * *$ & -16.0 & 0.066 & $1.80^{* *}$ & 0.26 & $-95.13 * *$ & $5.44 *$ & $-4.48^{* *}$ & $-4.86^{* *}$ & -0.377 & -4.28 & $1.29 *$ & $\mid-0.36 * *$ & $2.05^{*}$ & $6.11 * *$ & 8.40 & 0.27 & -0.77 & $-4.89 * *$ \\
\hline $\begin{array}{c}\text { A556 } \times \\
\text { USSR150 } \\
\end{array}$ & $-20.73^{*}$ & $-1.33 * *$ & 0.11 & 0.177 & $1.68^{* *}$ & $-1.06^{*}$ & $-70.68 * *$ & $-6.22 *$ & $4.84 * *$ & $4.022 * *$ & $-0.822 *$ & -0.19 & $2.42 *$ & $0.153^{*}$ & $2.37 * *$ & $4.33^{*}$ & $33.06 * *$ & $0.82 *$ & $-1.33^{*}$ & -0.368 \\
\hline $\begin{array}{l}\text { A556 } \times \\
150 P-1\end{array}$ & $12.82 *$ & $1.00^{*}$ & $34.66 *$ & $\mid-0.155$ & 0.46 & 0.26 & 11.75 & -0.11 & -0.600 & -0.088 & $0.511 *$ & -0.45 & 0.32 & -0.04 & -0.08 & $-3.21 *$ & -10.6 & 0.26 & $1.44 *$ & $-1.96^{*}$ \\
\hline
\end{tabular}

$\mathrm{PH}=$ plant height, $\mathrm{NOL}=$ number of leaves, $\mathrm{LA}=\mathrm{Leaf}$ area, $\mathrm{CL}=\mathrm{Cob}$ length, $\mathrm{CD}=\mathrm{Cob}$ diameter, $\mathrm{KR}=$ Kernel rows per ear, $\mathrm{K} / \mathrm{C}=\mathrm{Kernel}$ per ear, $\mathrm{L}$ ang $=\mathrm{Leaf}$ angle, $\mathrm{DS}=$ days to silking, $\mathrm{DA}=\mathrm{Days}$ to anthesis, Int $=$ Interval, $\mathrm{PY}=$ plant yield, $100 \mathrm{SW}=100$ Seed weight, $\mathrm{LR}=$ Leaf rolling, $\mathrm{LT}=$ Leaf temperature, Chl $=$ Chlorophyll content, $\mathrm{SS}=\mathrm{Stomata}$ size, $\mathrm{SF}=\mathrm{Stomata}$ frequency, $\mathrm{EC}=\mathrm{Epidermal}$ cells, $\mathrm{HI}=$ Harvest index 


\section{Conclusions}

The inbred lines W64TMS and W82-3 expressed higher general combining ability (GCA) for grain yield, and other yield related traits (cobs per plant, grains per cob, 100seed weight) under normal and water deficit conditions. The F1 hybrids W64TMS $\times$ USSR150 and W82-3 × 150P-1 showed higher SCA for grain yield and other related traits under normal and drought stress. It was suggested form our findings that the present breeding material may be used for the improvement of grain yield and water deficit tolerance in maize.

\section{REFERENCES}

[1] Abayomi, Y. A., Awokola, C. D., Lawal, Z. O. (2012): Comparative evaluation of water deficit tolerance capacity of extra-early and early maize genotypes under controlled conditions. - J. Agric. Sci. 4: 54.

[2] Ali, F., Ahsan, M., Ali, Q., Kanwal, N. (2017): Phenotypic stability of Zea mays grain yield and its attributing traits under drought stress. - Frontiers in Plant Science 8: 1397.

[3] Ali, Q., Ahsan, M., Ali, F., Aslam, M., Khan, N. H., Munzoor, M., Mustafa, H. S. B., Muhammad, S. (2013): Heritability, heterosis and heterobeltiosis studies for morphological traits of maize (Zea mays L.) seedlings. - Advancements in Life Sciences 1(1): 52-63.

[4] Ali, Q., Ali, A., Ahsan, M., Ali, S., Khan, N. H., Muhammad, S., Abbas, H. G., Nasir, I. A., Husnain, T. (2014): Line $\times$ Tester analysis for morpho-physiological traits of Zea mays L. seedlings. - Advancements in Life Sciences 1(4): 242-253.

[5] Ali, Q., Ahsan, M., Malook, S., Kanwal, N., Ali, F., Ali, A., Ahmed, W., Ishfaq, M., Saleem, M. (2016): Screening for drought tolerance: comparison of maize hybrids under water deficit condition. - Advancements in Life Sciences 3(2): 51-58.

[6] Anjum, S., Xie, A., Wang, X. Y., Saleem, L. C., Man, M. F., Lei, W. (2011): Morphological, physiological and biochemical responses of plants to drought stress. Afr. J. Agric. Res. 6: 2026-2032.

[7] Araus, J. L., Slafer, G. I.; Reynolds, M. P.; Royo. C. (2002): Plant breeding and water deficit in $\mathrm{C}_{3}$ cereals: what should we breed for? - Ann. Bot. 89: 925-940.

[8] Aslam, M., Maqbool, M. A., Cengiz, R. (2015): Drought Stress in Maize (Zea mays L.) Effects, Resistance Mechanisms, Global Achievements and Biological Strategies for Improvement. - Springer, Cham. DOI: 10.1007/978-3-319-25442-5.

[9] Athar, H. R., Ashraf, M. (2009): Strategies for Crop Improvement against Salinity and Drought Stress: An Overview. - In: Ashraf, M., Ozturk, M., Athar, H. R. (eds.) Salinity and Water Stress. Springer Science, Heidelberg.

[10] Awasthi, R., Kaushal, N., Vadez, V., Turner, N. C., Berger, J., Siddique, K. H. (2014): Individual and combined effects of transient drought and heat stress on carbon assimilation and seed filling in chickpea. - Funct. Plant Biol. 41: 1148-1167.

[11] Bänziger, M., Edmeades, G. O., Beck, D., Bellon, M. (2000): Breeding for Drought and Nitrogen Stress Tolerance in Maize: from Theory to Practice. - CIMMYT, Mexico.

[12] Bänziger, M., Edmeades, G. O., Lafitte, H. R. (2002): Physiological mechanisms contributing to the increased $\mathrm{N}$ stress tolerance of tropical maize selected for drought tolerance. - Field Crop Res. 75: 223-233.

[13] Campos, H., Cooper, M., Habben, J. E., Edmeades, G. O., Schussler. J. R. (2004): Improving drought tolerance in maize a view from industry. - Field Crops Res. 90: 1934.

[14] Cattivelli, L., Rizza, F., Badeck, F. W.; Mazzucotelli, E., Mastrangelo, A. M., Francia, E., Mare, C., Tondelli, A., Stanca, A. M. (2008): Drought tolerance improvement in crop plants: an integrative view from breeding to genomics. - Field Crop Res 105: 1-14. 
[15] Chen, D., Wang, S., Cao, B., Cao, D., Leng, G., Li, H., Yin, L., Shan, L., Deng, X. (2015): Genotypic variation in growth and physiological response to drought stress and re-watering reveals the critical role of recovery in drought adaptation in maize seedlings. - Front Plant Sci. 6: 1241.

[16] Chohan, M. S. M., Saleem, M., Ahsan, M., Asghar, M. (2012): Genetic analysis of water stress tolerance and various morpho-physiological traits in Zea mays, L. using graphical approach. - Pak. J. Nutr. 11: 489-500.

[17] Edmeades, G. O., Cooper, M., Lafitte, R., Zinselmeier, C., Ribaut, J. M., Habben, J. E., Löffler, C., Bänziger, M. (2001): Abiotic Stresses and Staple Crops. - In: Proceedings of the third International Crop Science Congress. CABI, Hamburg.

[18] Edmeades, G. O., McMaster, G. S., White, J. W., Campos, H. (2004): Genomics and the physiologist: bridging the gap between genes and crop response. - Field Crop. Res. 90: 518.

[19] Falconer, D. S., Mackay, T. F. C. (1996): Introduction to Quantitative Genetics. $4^{\text {th }}$ Ed. Benjamin Cummings, England.

[20] Farnham, I. M., Johannesson, K. H., Singh, A. K., Hodge, V. F., Stetzenbach, K. J. (2003): Factior analytical approaches for evaluating groundwater trace element chemistry data. - Anal. Chim. Acta 490: 123-138.

[21] Golbashy, M., Ebrahim, M., Khorasani, S. K., Chaukan, R. (2010): Evaluation of drought tolerance of some corn (Zea mays L.) hybrids in Iran. - Afr. J. Agric. Res. 5: 2714-2719.

[22] Ivy, N. A., Howlader, M. S. (2000): Combining ability in maize. - Bangladesh J. Agril. Res. 25: 385-392.

[23] Kakumanu, A., Ambavaram, M. M., Klumas, C., Krishnan, A., Batlang, U., Myers, E., Grene, R., Pereira, A. (2012): Effects of drought on gene expression in maize reproductive and leaf meristem tissue revealed by RNA-Seq. - Plant Physiol. 160: 846867.

[24] Kanwal, N., Ali, F., Ali, Q., Sadaqat, H. A. (2019): Phenotypic tendency of achene yield and oil contents in sunflower hybrids. - Acta Agriculturae Scandinavica, Section B - Soil \& Plant Science 13: 1-6.

[25] Kempthorne, O. (1957): An Introduction to Genetic Statistics. - John Wiley and Sons, New York, pp. 468-472.

[26] Konak, C., Unay, A., Serter, E., Basal, H. (2001): Estimation of combining ability effects, heterosis and heterobeltiosis using line $\times$ tester method in maize. - Turkish J. Field Crops. 4: 19.

[27] Kwon, S. H., Torrie, J. H. (1964): Heritability and interrelationship of trait of two soybean populations. - Crop Sci. 4: 196-198.

[28] Mahmood, T., Mustafa, H. S., Aftab, M., Ali, Q., Malik, A. (2019): Super canola: newly developed high yielding, lodging and drought tolerant double zero cultivar of rapeseed (Brassica napus L.). - Genetics and Molecular Research 18(2).

[29] Mao, H., Wang, H., Liu, S., Li, Z., Yang, X., Yan, J., Li, J., Tran, L. S., Qin, F. A. (2015): Transposable element in a NAC gene is associated with drought tolerance in maize seedlings. - Nat Commun. 6: 8326.

[30] Mendoza, M., Oyervides, A., Lopez. A. (2000): New maize cultivars with agronomic potential for the humid tropics. - Agronomia Mesoamericana 11: 83-88.

[31] Montgomery, K. R., Cheo, P. C. (1971): Effect of leaf thickness on ignitibility. - Forest Science 17(4):475-8.

[32] Moradi, R., Alizadeh, Y., Nezami, A., Eshghizadeh, H. R. (2013): Study of Lentil (Lens culinaris Medik.) seed size on germination and seedling properties in drought stress condition. - Iran. J. Field Crops Res. 11: 39-40.

[33] Nelson, D. E., Repetti, P. P., Adams, T. R., Creelman, R. A., Wu, J., Warner, D. C., Anstrom, D. C., Bensen, R. J., Castiglioni, P. P., Donnarummo, M. G., Hinchey, B. S. (2007): Plant nuclear factor Y (NF-Y) B subunits confer drought tolerance and lead to 
improved corn yields on water-limited acres. - Proc. Natl. Acad. Sci. USA 104: 1645016455.

[34] Nuccio, M. L., Wu, J., Mowers, R., Zhou, H., Meghji, M., Primavesi, L. F., Paul, M. J., Chen, X., Gao, Y., Haque, E., Basu, S. S. (2015): Expression of trehalose-6-phosphate phosphatase in maize ears improves yield in well-watered and drought conditions. - Nat. Biotechnol. 33: 862-869.

[35] Paul, S. K., Duara, R. K. (1991): Combining ability studies in maize (Zea mays L.). - Intl. J. Tropics. Agric. 9: 250-254.

[36] Pushpavalli, R., Zaman-Allah, M., Turner, N. C., Baddam, R., Rao, M. V., Vadez, V. (2014): Higher flower and seed number leads to higher yield under water stress conditions imposed during reproduction in chickpea. - Funct. Plant Biol. 42: 162-174.

[37] Rahbarian, R., Khavari-Nejad, R., Ganjeali, A., Bagheri, A., Najafi, F. (2011): Drought stress effects on photosynthesis, chlorophyll fluorescence and water relations in tolerant and susceptible chickpea genotypes. - Acta Biol. Crac. Ser. Bot. 53: 47-56.

[38] Rahman, H., Arifuddin, Shah, Z., Shah, S. M. A., Iqbal, M., Khalil, I. H. (2010): Evaluation of maize S2 lines in testcross combinations I: flowering and morphological traits. - Pak. J. Bot. 42: 1619-1627.

[39] Seghatoleslami, M. J., Kafi, M., Majidi, E. (2008): Effect of drought stress at different growth stages on yield and water use efficiency of five proso millet (Panicum miliaceum L.) genotypes. - Pak. J. Bot. 40: 1427-1432.

[40] Sehgal, A., Sita, K., Kumar, J., Kumar, S., Singh, S., Siddique, K. H. M., Nayyar, H. (2017): Effects of drought, heat and their interaction on the growth, yield and photosynthetic function of lentil (Lens culinaris Medikus) genotypes varying in heat and drought sensitivity. - Front. Plant Sci. 8: 1776.

[41] Sehgal, A., Sita, K., Siddique, K. H. M., Kumar, R., Bhogireddy, S., Varshney, R. K., HanumanthaRao, B., Nair, R. M., Prasad, P. V., Nayyar, H. (2018): Drought or/and heatstress effects on seed filling in food crops: impacts on functional biochemistry, seed yields, and nutritional quality. - Front. Plant Sci. DOI: 10.3389/fpls.2018.01705.

[42] Sevanto, S. (2014): Phloem transport and drought. - J. Exp. Bot. 65: 1751-1759.

[43] Sindagi, S. S., Kulkarni, R. S., Seetharam, A. (1997): Line $\times$ tester analysis of the combining ability in sunflower (Helianthus annuus L.). - The Sunflower Newslet. 3: 1112.

[44] Steel, R. G. D., Torrie, J. H., Dicky, D. A. (1997): Principles and Procedures of Statistics. A Biometrical Approach. 3rd Ed. - McGraw Hill Book Co. Inc., New York, pp. 400-428.

[45] Valentovic, P., Luxova, M., Kolarovic, L., Gasparıkova, O. (2006): Effect of osmotic stress on compatible solutes content, membrane stability and water relations in two maize cultivars. - Plant Soil Environ. 52: 186-191.

[46] Yordanov, I., Velikova, V., Tsonev, T. (2000): Plant responses to drought, acclimation and stress tolerance: review. - Photosynthetica 38: 171-186. 


\section{APPENDIX}

Table A1. Mean squares values from analysis of variance for yield related traits in maize accessions

\begin{tabular}{|c|c|c|c|c|}
\hline Source of variation & Genotypes (G) & Treatments $(\mathrm{T})$ & $\mathbf{G} * \mathbf{T}$ & Error \\
\hline Degree of freedom & 49 & 1 & 49 & 198 \\
\hline Plant height & $2228.9 * *$ & $43176.0 * *$ & $1852.6 * *$ & 1.0 \\
\hline Number of leaves & $6.758 * *$ & $322.403 * *$ & $11.526 * *$ & 0.354 \\
\hline Cob length & $9.765 * *$ & $340.204 * *$ & $8.627 * *$ & 0.158 \\
\hline Leaf area & $54289 * *$ & $1602498 * *$ & $25165^{* *}$ & 2 \\
\hline Cob diameter & $5.084 * *$ & $377.149 * *$ & $5.690 * *$ & 0.264 \\
\hline Kernel rows & $8.713 * *$ & $979.213 * *$ & $8.193 * *$ & 1.302 \\
\hline Kernels per cob & $18887 * *$ & $119920 * *$ & $17080 * *$ & 6 \\
\hline Grain yield & $893.8 * *$ & $41564.6 * *$ & $1047.9 * *$ & 3.2 \\
\hline 100 seed weight & $35.81 * *$ & $2856.53 * *$ & $56.78 * *$ & 1.20 \\
\hline Leaf angle & $218.856^{* *}$ & $110.413 * *$ & $249.475 * *$ & 0.515 \\
\hline Leaf rolling & 412.97 & 1565.68 & 412.76 & 409.36 \\
\hline Days to $50 \%$ silking & $32.32 * *$ & $1391.05 * *$ & $46.50 * *$ & 5.58 \\
\hline Days to $50 \%$ anthesis & $39.60 * *$ & $2809.08 * *$ & $58.07 * *$ & 5.69 \\
\hline Anthesis-silking interval & $4.510 * *$ & $246.613 * *$ & $4.491 * *$ & 0.101 \\
\hline Leaf temperature & $57.69 * *$ & $4396.84 * *$ & $51.84 * *$ & 0.73 \\
\hline Chlorophyll content & $289.5 * *$ & $64102.9^{* *}$ & $343.6^{* *}$ & 0.5 \\
\hline Stomata size & $15318 * *$ & $1423663 * *$ & $16476^{* *}$ & 49 \\
\hline Stomata frequency & $9.882 * *$ & $257.613 * *$ & $12.770 * *$ & 1.329 \\
\hline Epidermal cells & $20.885^{* *}$ & $657.120 * *$ & $20.467 * *$ & 1.600 \\
\hline Harvest index & $37.2 * *$ & $11325.3 * *$ & $31.2 * *$ & 0.3 \\
\hline
\end{tabular}

**Highly significant differences $(\mathrm{P}<0.01)$; Df = degree of freedom; SOV = source of variation 